\title{
Byzantine Philosophy: Transfiguration of Man in the Tabor Light Doctrine of Gregory Palamas
}

\author{
Olga V. Chistyakova ${ }^{1, *}$ \\ ${ }^{1}$ Department of History of Philosophy, Peoples' Friendship University of Russia (RUDN University), 6 \\ Miklukho-Maklaya Street, Moscow 117198, Russian Federation \\ *Corresponding author. Email: chistyakova-ov@rudn.ru
}

\begin{abstract}
The anthropological issues of philosophy of the late period Byzantium are under consideration in the article. The particular attention is paid to the substantiation of the Tabor Light conception of Gregory Palamas, a founder of Byzantine Hesychasm. Palamas' Uncreated Light (Tabor) doctrine is submitted concerning his teaching on God's energies and his understanding of the human being. The author shows the essential change of the Human being in connection with his perception of the Divine Light, i.e., the transfiguration of Man by the Light. Some provisions of Hesychasm connected with religious gnosis and the possibilities of the human mind in the knowledge of the Godhead are considered.
\end{abstract}

Keywords: Man in Byzantine philosophy, Hesychasm, Transfiguration of God and the Human being, Theology of Chrisitianity.

\section{INTRODUCTION}

Anthropological ideas of the Eastern Christianity 1 are correlated with the epistemological religious conceptions, appeared within the frame of the Greek-Byzantine theology and philosophy. The religious gnosis was manifested in different God-knowing doctrines, which referred to the sphere of personal achievement of the Creator. The Christian thinkers defined this epistemological realm as merely personal or mystical because it revealed an individual experience of a human on his ascending path to God. In this context, theologians justified the God-knowing steps both as self-knowing and self-perfecting of a man, being cherished the desire to comprehend the highest Divine knowledge. Thus, the notions of

*Fund: The reported study was funded by RFBR and MOST according to the research project N 20-511-S52002 "Philosophy of Being Human as the Core of Interdisciplinary Research."

1. The Eastern Christianity implies forming the Christian religion throughout the Byzantine empire from the IVth to the XVth centuries. In this process, the Nicene and postNicene Church Fathers' writings obtained paramount importance, and the later treatises of Paul of Latria, Symeon the New Theologian, Gregory Palamas, etc., were the founders of the mystical tradition of Christianity. mystical and personal coincide in the Byzantine epistemology.

The core idea of religious Christian gnosis is a thesis, pronouncing the Divine nature of the human beings granted by the Trinity from the very creation of the First Men. This divinity, or God's image in Man, allows each person to strive for God-knowing and reach a state of unity with Him, being embraced by cherished deification. The Eastern Church Fathers considered the process of Godknowing as a person's eternal spiritual selfperfecting, as the holistic transformation of the fallen nature of Man into the absolute one. This idea was made real in the dominated conception of spiritualization of both soul and body in Byzantium. In their turn, it urged the theoretical substantiation of the anthropological phenomena of the spiritualized person in medieval Byzantine philosophy.

Therefore, it was pretty predictable that the mystical-personal path of dialogical communication of the human being with God was gradually shaped in the Greek-Byzantine culture. It aimed precisely at individual comprehension of the Divine knowledge in the sacral unity of Man and God. It signified the deification of a person, i.e., his 
attainment of absolute, truly divine qualities employing the human's nature perfecting. It was characterized as if a Divine being merges with a human being in the highest form of interrelation.

Byzantine theologians substantiated the craved unity of a person with God, elaborating different conceptions and methods. In this article, I pay attention to one of them - it is a path of Godknowing through the perception of the uncreated Divine Light, or Tabor Light, presented in Saint Gregory Palamas' legacy.

\section{THE TABOR LIGHT CONCEPTION AS AN ANTINOMIAN DOCTRINE OF GOD-KNOWING}

In general, the basis of Palamas' anthropology and epistemology is embraced by the antinomic idea, which reveals the human's possibilities of knowing the Triune God, Who is simultaneously intelligible phenomenally and incognizable in His essence. More detailed, antinomianism of Christological theology manifested in the Godknowing doctrine as the inaccessibility of the Creator's absolute nature and a real possibility of "meeting" a human being and God. I contend that these passages primarily defined the peculiarity of Byzantine philosophy and the Greek-Byzantine theology. In these terms, Gregory Palamas is a follower of the orthodox Christian God-knowing teaching, shaped during the Nicene and post-Nicene Patristics periods. The Church Father deepened it by developing the Tabor Light doctrine and the conception of God's energies. He was formulating the fundamental theological idea of the unknowability of God's essence, of His transcendental being, and, at the same time, His revelation to the mundane world and His actual presence in the earthly life. Thus, St. Gregory, from the Hesychasm position, started to elucidate the cognizability of incognizable God's nature, using the philosophical and religious conception of God's energies as His phenomena.

Gregory Palamas' doctrine on God's energies is tightly connected with his mystical teaching on the Divine Light, recognizing as "uncreated" and referable to the essence of Trinity. Palamas and his disciples' understanding of the Light determined their anthropology and caused the philosophical substantiation of the human being. According to Palamas, a person's spirituality and inner life might be penetrated by the Divine Light. St. Gregory gives it the name Tabor after Mount Tabor, where Christ was transfigured and where he shone with the uncreated Light in the face of his three disciples, Peter, Jacob, and John.

In terms of the Tabor Light conception, St. Gregory justified a philosophical and theological issue of the interrelationship of God's essence and His energies. The Byzantine thinker stays there on the early Church Fathers' tradition to discuss God's essence. It is incognizable, but God is not identical with His essence in that $\mathrm{He}$ emanates from it outside. God's existence addressing outward things should be named God's will, or energy, which is revealed and conveyed to all the people communicating with God. Thus, Palamas calls Christ "the Light" and His activity "the enlightenment." He wrote: "Let us follow, the brothers, the Light, which enlightens both our soul and body" [1].

The Palamas' understanding of the notion "light" clearly explains the Russian philosopher Vladimir Losskiy in his manuscript on the Eastern theology: «This light $(\phi \tilde{\omega} \varsigma)$ or effulgence $(\varepsilon " \kappa \lambda \alpha \mu \psi \imath \varsigma)$ can be defined as the visible quality of the divinity, of the energies, or grace in which God makes Himself known. It is not a reality of the intellectual order, as the illumination of the intellect, taken in its allegorical and abstract sense, sometimes is. Nor is it a reality of the sensible order. This light is a light which fills at the same time both intellect and senses, revealing itself to the whole man, and not only to one of his faculties" [2].

Early Church Fathers, discussing an issue of Christ's Transfiguration, stress the Divine spiritual nature of the Light, revealed to the three Apostles. Gregory of Nazianzus, Athanasius of Alexandria, Maximus the Confessor, Symeon the New Theologian, and others were the followers of that tradition. St. Gregory Palamas develops this doctrine, connecting it with the mystical experience of Hesychasm. The most important event for the Hesychasts was the Transfiguration of the ChristSavior in which the relation of a man with God was considered as fusion of Light acceptance and the dialogue of Jesus with His disciples-the monks [3]. According to the Eastern Patristics, the Apostles "saw" the Divine Light on the Tabor Mountain, and that Light was inherent to God as His essence. The Light is uncreated, but Christ's disciples could feel it peculiarly. The Divine Light, which transfigured Christ, is a medium for man to reach the transcendent God. The phenomenon of the Light is preceded by both the contemplation of a sensual light related to the physical vision and the light of mind as the source of thinking. The merely 
beholding of the Tabor Light simultaneously by both the super-sensitive and sensitive visions that might be achieved only by the tacit prayer - a specific mystical practice - was the main goal of the Mount Athos' Hesychast monks.

Per St. Gregory, Jesus Christ intended to reveal something omnipotent and mysterious to His disciples. Thus, He transfigured before them in the prayer [4]. Palmas elucidates that the Savior shines with the "ineffable" Light purposely in the prayer. Thereby, Christ manifested that prayer is a proffer of the Divine vision, and a person ascending to God can perceive the uncreated Light through the prayer and moral virtues, being transfigured by the Light at this point. Absolute truth and beauty can be seen and accepted only by a human, purified a mind and a soul. Then a man becomes illuminated themselves and reaches a spiritual state of unification with God.

St. Gregory underlines the uncreated and transcended nature of the Divine Light, which, nevertheless, appeared before the three disciples as God's energies. Thus, he contended and its immanence to the mundane world. Palamas' heritage researcher John Cheng writes in this context: «Palamas' God is a transcendent-immanent God who is transcendent in His Essence and yet at the same time immanent to us through His Energies. Hence, Palamas' God can be called a divine transcendent-immanent being or the Divine Essence-Energy Being. This transcendentimmanent concept of God helps us comprehend better how God can be hidden and revealed to us simultaneously. It provides us with authentic Christian immanence, as it expands the horizon of our traditional Platonic transcendental tendency to identify the supernatural primarily with the transcendent" [5].

The Divine Light was depicted both as the meaningful image of Christ's uncreated essence and a symbol of conciliar unity between man and God. In these terms, Gregory Palamas elaborated the anthropological conception of being human in a necessary connection with the Creator.

\section{THE ANTHROPOLOGICAL FOUNDATIONS OF THE TABOR LIGHT DOCTRINE}

Hesychasm modifies the Eastern Christian tradition of considering the energies of God by conceptualizing them in an anthropological way. Energy is the practical beginning and the central point of man's attainment of mystical knowledge of the Creator. Russian philosopher S.S. Khoruzhiy describes the essence of energies in connection with the concept of deification: «...synergy and Deification are nothing other than a combination of human energies and Divine energy, grace» [6 ].

The state of luminosity, unity with God, deification, according to St. Gregory, cannot be achieved only by the creative impulse of man. God, by His grace, helps him to do this. At the same time, the Byzantine thinker rejects the view that receiving grace depends only on the will of man. In this matter, he traditionally stands on the interaction of Divine grace and man's free will. In his view, every person is a divine chosen one. "People differ only in the variety of charismatic gifts, talents, and ability and willingness to accept divine grace." [7]

Divine grace is the Light enabling spiritually healthy people to encounter God. According to Gregory Palamas, man's inner life must be attuned by the effort of his will to perceive and experience God. One must learn to comprehend one's soul to realize the phenomena of mystical life in lightbearing unity with God. The mystical Hesychast acceptance of God means attaining a higher knowledge accompanied by incredible spiritual pleasure, a religious ecstasy.

Gregory Palamas insisted on the spiritual activity of man. The one reaching communion with God cannot remain outside the Light. If the ascetic is suddenly seized by "darkness," it is because his life has been influenced by sin, or God is testing him to make him stronger. These conditions are overcome by obedience and humility. Then God will respond by reappearing in the soul and heart of the Hesychast, communicating His light to the human being. «The man who has become a partaker of the divine action and has been changed by the divine change, himself becomes like a light, and remains with the light $\langle\ldots\rangle$ because those who have purified their heart see God, <...> who being Light dwells in them and reveals himself to those who love him and love him» [8].

Gregory Palamas defends the thesis that the Divine Light is uncreated and is inherent in God in eternity, but it is not his essence. Light in St. Gregory's understanding is a phenomenon of the essence of God, an expression of his transcendence, a way of "communication," a dialogue between the Trinity and a person. No one can be "in the very life and substance of God". Saints and apostles can contemplate the radiance of the Light of Tabor, but even they do not comprehend the essence of the 
Creator. There is no moral, bodily, or any other obstacle to perceiving the Divine light. Only an appropriate way of righteous living is the main condition for attaining luminous unity with God. Here Palamas argues in the spirit of the preceding Christian tradition.

To see the Divine Light "bodily eyes," one shall be a partaker of that Light, to be changed by it. The mystical experience of Hesychasm presupposed the transfiguration of human nature under the action of grace and self-purification. Spiritual enjoyment of the Tabor Light is possible only through the active position of the subject, actively forming and preparing his inner world for the encounter with God. The Divine energy completes this formation in the luminous transformation of the human essence. Palamas urges the ascetics to raise "the eyes of the soul" and, accumulating in this way the Divine illumination, to become conformed to the Creator. One must rise above oneself, one's feelings, one's affections, one's attraction to the outer world. «To become truly close to God is not possible unless, in the process of purifying ourselves, we are outside ourselves, or better said, above ourselves, leaving with the senses all that is perceived by the senses, rising above reasoning and conclusions and all knowledge and thoughts themselves; being entirely at the action of the spiritual sense, and achieving this - beyond all knowledge - ignorance» [9]

The ignorance of which St. Gregory speaks is above knowledge. However, the ignorance is above all earthly knowledge, experience, and science. Consequently, what is meant is a higher knowledge, which is expressed in attaining a state of the superconscious and supersensible, even somewhere superhuman. If knowledge is compared to light, then ignorance is light over light. It is the pinnacle on the road to God. The "darkness" that mysteriously "illuminated" God also does not belong to earthly categories. The organs of sight could not perceive the Divine Light, so it is given the mystical term "darkness." Darkness is unapproachable light.

In this context, ignorance is the highest knowledge that one acquires as one gets closer to God. Man, who has reached this stage of knowledge, needs no more ordinary knowledge or sensual data. He is above it all. Thus, Gregory Palamas posits the ascetic goal of attaining ignorance as the knowledge that exceeds the mind, earthly knowledge, and experience, resulting from the gracious illumination of the soul as it approaches God in spiritual asceticism.

The goal of the ascetics and secular righteous men, from the point of view of Hesychasm, is not simply victory over temptations to be sinless before God, and not only moral self-improvement, moral and spiritual likeness to Christ. These are only steps to its highest goal - the transformation, the deification of all human nature, soul, and flesh. Moreover, this should happen not in the afterlife but here on earth, preserving human personality with its ontological essence and independent will.

Thus, the highest stage of mystical knowledge of God ${ }^{2}$ is seeing and perceiving the Divine Light. It fills the human person who has achieved unity with God. It is no longer a transitory state but a conscious life in the light, in constant communion with God. In luminous unity with the Creator, man's covenantal likeness to God, the return of his lost likeness to God, is possible. In the state of luminosity, man is saturated with the Divine energy, entirely transformed by it, his body and soul radiate light, and man achieves deification in the complete unity of his soul and body.

\section{CONCLUSION}

The Tabor Light theory developed by St. Gregory Palamas and his followers, the Hesychasts, is shown as a continuation and peculiar development of the anthropological concept of Eastern Christianity. The concept of the uncreated Tabor Light is presented as an original achievement of the Greek-Byzantine tradition of Christianity. Palamas' doctrine is considered from the point of view of the antinomian principle, as simultaneous inaccessibility and attainability of the Divine Light, and thus the knowledge of God. In the teachings of St. Gregory, the Tabor Light is presented as the energies of God, perceived by people, and thereby contributing to the knowledge of the man himself. The article particularly emphasizes the role of the Light of Tabor for the purification and transformation of man himself, who has taken the path of righteousness and monasticism. The Hesychast spiritual tradition completes the philosophical and religious consideration of the problem of man in Byzantine culture.

2. Concerning the mystical tradition of God-knowing in Greek-Byzantine Christianity, it is possible to read more details in the article written by Nur Kirabaev and Olga Chistyakova in the Journal Religions, 2020, 11 [10]. 


\section{AUTHORS' CONTRIBUTIONS}

This paper is independently completed by Olga V. Chistyakova, including conceptualization, methodology, investigation, writing - original draft preparation, writing - review, and editing, resources.

\section{REFERENCES}

[1] Saint Palamas Gregory. The Homilies, in 3 vol. Vol. 3. M.: Palomnik, 1993, p. 116.

[2] Losskiy V.N. The Mystical Theology of the Eastern Church. Crestwood: St Vladimir's Seminary Press, 1976. Online. Available at https://azbyka.ru/otechnik/Vladimir_Losskij/t he-mystical-theology-of-the-easternchurch/\#0_11 [Accessed: 28.06.2021]

[3] Anita Strezova. Byzantine Hesychasm in the 14th and 15th Centuries, in Hesychasm and Art. ANU Press. 2014. Pp. 1-54. Online. Available at https: // www.jstor.org/stable/j.ctt13www4f.9

[4] Saint Palamas Gregory. The Homilies, in 3 vol. Vol. 2. M.: Palomnik, 1993, p. 88.

[5] John Cheng. The Distinction between God's Essence and Energy: Gregory Palamas' idea of Ultimate Reality and Meaning. Online. Available at: https://www.academia.edu/36294128/The_Dis tinction_between_Gods_Essence_and_Energy _Gregory_Palamas_idea_of_Ultimate_Reality _and_Meaning. [Accessed: 27.03.2021], p. 98.

[6] Khoruzhiy S.S. Hesychasm as a Philosophy Space, in Russian Studies in Philosophy. 1995, № 9, p. 83.

[7] Ekonomtsev I.N. Orthodoxy. Byzantium. Russia. M.: Christian Literature. 1992, p. 181.

[8] Saint Palamas Gregory. The Homilies, in 3 vol. Vol. 3., pp. 134-135.

[9] Ibid., p. 116

[10] Kirabaev, N.; Chistyakova, O. Knowing God in Eastern Christianity and Islamic Tradition: A Comparative Study. Religions 2020, 11, 675. https://doi.org/10.3390/rel11120675 